The primary and indeed essential need is for science to be represented from the very beginning on the Secretariat of U.N.E.S.C.O. The secondary action may well be for us, first nationally and then internationally, to make the existing or new scientific organizations of various types both representative and efficient so that they can claim recognition from U.N.E.S.C.O. at an early stage. The proposals put forward by the Association of Scientific Workers, as representing the work which the scientific division of U.N.E.S.C.O. should do, are admirable but they would take several years to bring to fruition, and demand a large and highly qualified administrative staff at a moment when there is a great dearth of seientific workers for productive work. Moreover, the question arises whether all these matters should be handed over to bureaucrats, for that is what they will become, even though they started as men of science. The docile are not always the virtuous. Is it not wiser to maintain the freedom which we cherish, which some think we are in danger of losing, and organize these things for ourselves while becoming closely affiliated to the world organization ?

There is so much to do to-day that we are accustomed to priorities in every sphere of activity. U.N.E.S.C.O. must have priorities, some undoubtedly far higher than the claims of advanced science : this is the main reason why we must do some things for ourselves if they are to be done soon.

Happenings the world over rightly interpreted may be taken as evidence of strength in our civilization. The responsibility for the recreation of the moral life of the world will fall heavily on us; in this we dare not fail. As R. A. Butler wrote the other day, the Conference "must ensure that the world of Education, like that of Science, does not become the plaything of purely Governmental machinery, either in any one country or in any international organisation".

In the next few months U.N.E.S.C.O. will have to establish its organization. It has a precedent in the International Labour Office. The Executive Board is representative of eighteen governments and elected by the Conference ; there is to be a directorgeneral and a permanent secretariat. Perhaps it should at once break down its work into sections, of which science will undoubtedly be one. Men of science should proceed without delay to set out in clear and, above all, practical terms, avoiding too great a length, the work and problems which this Science Section should envisage as its first tasks. It must be remembered that the non-scientific workers have still to be educated regarding the nature and the value of the help which the scientific attitude of mind can give them; at present they are sceptical, even suspicious of the motives of men of science and confused by the scientific habit of speaking with so many contrary voices on any subject.

The Conference was well attended, several countries sending large and influential delegations. As always on these occasions, perhaps most was effected by private conversations or smaller meetings, among which were several for the scientific delegates.

Many delegates were closely connected as teachers with education in their own countries, including some of the more backward in the educational sense. They were outspoken in the benefits which U.N.E.S.C.O. could give them : money spent on education instead of armies, a life in which cultural interests, the drama, art, science and literature could play a part instead of power politics and the fear of future war; a life in which mutual understanding and knowledge instead of ignorance of each other's ways and lives could be developed; a life of travel and interchange of visits (extending over weeks and months) of children, students, teachers, professors, research workers, all men and women of sympathy and goodwill promoting peace and an international outlook instead of narrow nationalism and suspicion; a life in which technical progress was for the service of man and not for his destruction.

\section{INSTITUTION OF METALLURGISTS}

\section{INAUGURAL MEETING}

$\mathrm{A}^{\mathrm{s}}$ $\mathrm{S}$ a craft, the metallurgical art is of the greatest antiquity: in the speculative development of natural science, the metals have played an important part. During the Middle Ages, the Guilds and Livery Companies exercised a beneficial influence in de. manding proofs of competence from the craftsmen working with metals; but as the importance of these bodies decreased, this control diminished, and since then, until the last few weeks, there was no organization, in Great Britain at least, which was responsible for certifying metallurgists as being professionally competent. University qualifications are clear proof of this ; but there are many who, for reasons outside their own control, have never had the opportunity of obtaining such training or 'hall-mark'.

In the Iron and Steel Institute and the Institute of Metals, Britain possesses two bodies which have done great service to the metallurgical industries, and to the community in general, as the avenues through which metallurgical research and developments have been made known; but membership of neither is recognized as proof of more than interest in the ferrous or non-ferrous metals.

For some years, there has been a growing feeling that a strictly professional body, somewhat similar to those which exist for chemists and engineers, was needed, and the two Institutes have had the matter under consideration. It was ultimately decided that the demand would be best met by the establishment of a new organization, admitting only qualified workers in the field of metallurgy, and having functions supplementary to, and independent of, the two existing metallurgical institutes.

On September 15, 1945, the new Institution of Metallurgists was incorporated and licensed by the Board of Trade, and on November 28 the inaugural meeting was held, under the presidency of Dr. H. Moore, at 4 Grosvenor Gardens, London, S.W.1, the offices of all three bodies. Attended by metallurg. ists of repute in all branches of the art and sciencethe presence of Prof. T. Turner, the doyen of English academic metallurgists, gave, perhaps, the greatest pleasure-and with the support of representatives of very many similar scientific and professional societies, the support and collaboration of which will be most welcome, the Institution was launched under conditions of the most complete harmony.

After outlining the reasons for the formation of still another society, Dr. Moore expressed his and the Institution's satisfaction at the presence of so many distinguished guests, and pointed out that the Institution was still under the control of a "caretaker government' until the first general election of officers to be held in the earlier part of next year. He then introduced the Hon. R. G. Lyttelton, treasurer 
of the Iron and Steel Institute, who on behalf of one of the 'parents' wished the Institution every success. Dr. W. T. Griffiths, president of the Institute of Metals, followed and reminded the meeting of the work done by the late Dr. T. Swindon in the early days of the discussions which had that day come to fruition. Throughout, the assistance of the two parent organizations was most cordially acknow- ledged. The value of the work of Dr. Moore himself, and that of Mr. K. Headlam-Morley, the secretary of both Institutes and of the new Institution, was stressed by Dr. J. W. Jenkin, vice-president, without which the formation of the Institution would have been considerably delayed.

To these gentlemen and to the two Institutes, the Institution of Metallurgists owes a very deep debt.

\section{NEWS and VIEWS}

\section{Science and Reconstruction}

IN addressing the Manchester Joint Research Council on "Science and Reconstruction" on December 6, Sir John Anderson referred to his own early career to emphasize that a good grounding in natural science can be a passport to the higher Civil Service and that publie administration does provide scope, apart from the professional or specialist grades, for men with a scientific training. Sir John associated himself with the view that the restoration of the economic life of Britain, and even the maintenance of pre-war standards of living, depends on building up our industries to a level of efficiency higher than ever before attained; and in support of this view he referred to some outstanding British technical achievements during the War to establish his contention that, while we have lagged behind in the past and men of science have to get rid of prejudice against applied science, the prognosis for the application of science in industry during the period of reconstruction is extremely favourable. Considering what is still needed, Sir John dealt first with the question of personnel. The output of scientific workers is below that which the real needs of the country demand, and too little was made of the importance of scientific and technical education during the passage of the Education Bill last year ; indeed, the needs of industry may at first have to give way to those of the universities. Urging the importance of preparing a quantitative and qualitative estimate of future requirements of trained men and women, Sir John welcomed the appointment by the Lord President of the Council of a committee to deal with the question of scientific man-power and also pressed for accelerating the release from the Forces of trained men of science and students.

Dealing next with the question of finance and the recent increased Government grant to the universities of Britain and to the new allowances in regard to tax relief for research expenditure, Sir John instanced a number of recent university endowments by industry as illustrating the value of such relief. He believes that so far as financial aid is concerned, we have a framework within which all that is required can be secured. The efficient use of the limited resources of Britain, however, demands the best possible organization, and here Sir John suggested as worthy of exploration a number of questions in regard to remumeration, mobility and interchange of staff and information or ideas, pensions schemes and the like on the lines of the recommendations in the recent Barlow Report on scientific staff. Research in applied science in teaching institutions should not be discouraged, though they should not be encouraged to undertake agency or contract work. The advantage of allowing some fundamental research in industrial research establishments should be recog- nized, and industrial associations might discuss with representatives of the universities and Government research organizations long-term programmes of research and what fundamental researches can most profitably be conducted in Government establishments or centrally in selected institutions.

Sir John Anderson unhesitatingly rejected the idea of a Minister of Science and suggested that the Lord President of the Council should be formally recognized as the Minister responsible for dealing, on behalf of the Cabinet, with all general scientific questions in which the Government is concerned, including problems of organization and arrangements for Commonwealth or international conferences. The Scientific Advisory Committee should be placed on a peace-time footing with some extension of staff, as the principal adviser of the Lord President and the Cabinet in scientific matters. Sir John would also create a special section of the Cabinet secretariat to assist the Lord President in the discharge of his new responsibilities. Finally, referring to the investigations into atomic energy, Sir John said that nothing had been discovered to justify the expectation that the energy released by an atomic explosion could be used directly as a source of industrial power. The only practicable method appeared to depend on the conversion into heat of the energy released by a controlled process of nuclear fission. The vast range of new radioactive substances, including radioactive forms of common elements used in medicine, which the new devices provide is probably much more important and beneficial and may bring a revolution in medical science.

\section{Industrial Research in Great Britain}

The Industrial Research Bill introduced into the House of Lords on November 29 by Lord Barnby was withdrawn after a speech by Lord Pakenham in which he indicated that although there was no active opposition to the principle of an enabling Bill, only about a dozen industries out of the eighty or ninety consulted by the Government on their postwar problems had indicated that they might take advantage of such legislation to finance any of the joint activities mentioned. Owing to the extreme pressure on parliamentary time during the present session, the Government would be unable to give facilities for the Bill; but whatever might be the position in the future, finance is not at present the main trouble. After referring to the announcement of the Lord President of the Council in his speech on November 6, Lord Pakenham emphasized that the Government appreciates that in some industries a statutory levy would give research associations the security of revenue necessary to allow them to plan useful long-term research and would have other advantages. Accordingly, the Government had the 